\title{
APLICAÇÃO DOS NÚCLEOS DE SIGNIFICAÇÃO COMO MÉTODO DE ANÁLISE PARA ENTREVISTA: A ESCOLHA PROFISSIONAL DE UM ADOLESCENTE
}

\section{APPLICATION OF THE MEANING CORE AS METHOD OF ANALYSIS OF AN INTERVIEW: THE PROFESSIONAL CHOICE OF ONE TEENAGER}

\author{
José Edson da Silva*
}

\begin{abstract}
RESUMO
Este artigo tem como objetivo aplicar a análise dos núcleos de significação como instrumento para apreensão dos sentidos da escolha profissional para um adolescente. Foi realizada entrevista semiestruturada com base em dezessete perguntas norteadoras com a finalidade de identificar os principais aspectos relacionados à escolha profissional do jovem no final do ensino médio numa escola pública sob o viés contextualizado de um pequeno município no qual está instalada uma grande indústria. Foram debatidas no decorrer das fases da análise a ausência da prática da orientação profissional e suas implicações. Seguiu-se o roteiro da elaboração de quadros de pré-indicadores e indicadores, com a posterior análise intranúcleos e internúcleos, respeitando o método recomendado nas análises dos núcleos de significação. Ao final entende-se que houve aproximação das zonas de sentido contidas na fala do sujeito, dessa forma o instrumento utilizado mostrou-se relevante na análise dos significados.
\end{abstract}

Palavras-chave: Sentidos; núcleos de significação; escolha profissional; adolescente.

\begin{abstract}
This article aims to apply the analysis of the core of meaning as an instrument to apprehend the senses of professional choice for an adolescent. A semistructured interview was conducted based on seventeen guiding questions with the purpose of identifying the main aspects related to the professional choice of the young person at the end of high school in a public school under the contextualized bias of a small municipality in which a large industry is installed. During the phases of the analysis, the absence of the practice of professional orientation and its implications was discussed. We followed the script for the preparation of tables of pre-indicators and indicators, with subsequent analysis intranuclei and internuclears, respecting the method recommended in the analysis of the core of meaning. At the end it is understood that there was approximation of the areas of senses contained in the speech of the subject, in this way the instrument used proved to be relevant in the analysis of meanings.
\end{abstract}

Keywords: Senses; meaning core; professional choice; adolescent.

“Técnico em Mecânica pela UNESP; Tecnólogo em Mecânica pelas Faculdades Integradas de Cruzeiro; Especialista em Gestão da Produção pela UNESP; Mestre em Desenvolvimento Humano pela UNITAU; Industriário a 25 anos com atuação na região do Vale do Paraíba paulista. 


\section{INTRODUÇÃO}

As pesquisas qualitativas se baseiam em métodos de coleta e análise de dados de caráter subjetivo, portanto tem o permanente desafio de criar e aprimorar instrumentos que permitam a aproximação dos objetivos estudados acerca do ser humano. Constitui complexa tarefa tal tratamento de dados, em que pese o papel do pesquisador enquanto analista de tais dados e responsável por trata-los de maneira que possa ser extraído o maior número possível de elementos contidos nas falas do indivíduo, buscando com isso maior proximidade no entendimento dos significados e sentidos.

A partir deste entendimento é identificada a relevância das análises por meio de núcleos de significação como instrumento que permite o aprofundamento mais efetivo na apreensão dos sentidos permeados nas falas do indivíduo, cuja forma de apresentação direta se dá através dos significados. Portanto, trata-se de um processo construtivo de compreensão daquilo que é falado por um sujeito na extração de causas que construíram esta fala, que por não raras vezes, o próprio sujeito desconhece. Revela-se a relevância da historicidade do indivíduo como constituinte de sua atual identidade, elucidando perguntas até então sem respostas, feitas pelo próprio sujeito no seu processo de autoconhecimento. A esse respeito diz-se que:

[...] na perspectiva de melhor compreender o sujeito, os significados constituem o ponto de partida: sabe-se que eles contém mais do que aparentam e que, por meio de um trabalho de análise e interpretação, pode-se caminhar para as zonas mais instáveis, fluidas e profundas, ou seja, para as zonas de sentido. Afirma-se, assim, que o sentido é muito mais amplo que o significado, pois o primeiro constitui a articulação dos eventos psicológicos que o sujeito produz ante uma realidade (AGUIAR e OZELLA, 2013, p.304).

O presente estudo pretende tomar como objeto de análise uma entrevista realizada com um adolescente que cursava o terceiro ano do ensino médio numa escola pública localizada no Vale do Paraíba paulista, na qual o objetivo central da pesquisa foi compreender o processo de escolha da profissão pelo indivíduo. Um viés peculiar do contexto estudado acrescenta ao tema da escolha profissional na adolescência, diversificado por si só, outro elemento - a presença de uma grande indústria num pequeno município. Este contexto foi tema de dissertação de mestrado (SILVA, 2016) no qual os dados foram tratados por meio do método da análise de conteúdo de Bardin (2011), organizados através de um processo de categorização.

Com o objetivo de analisar a fala do sujeito sob a perspectiva de outro instrumento, houve a motivação de selecionar um dos sujeitos da pesquisa mencionada (SILVA, 2016) para aplicação dos métodos dos núcleos de significação.

Em tempo, verifica-se em vários momentos do presente trabalho reflexões sobre a relevância da orientação profissional e a insistência na sua baixa penetração nas escolas e na sociedade de forma geral.

\section{SOBRE OS NÚCLEOS DE SIGNIFICAÇÃO}

Numa análise por meio de núcleos de significação é fundamental a utilização de algumas categorias durante todo o processo de interpretação e inferência sobre a fala do indivíduo. São elas mediação, historicidade, necessidade e motivos (AGUIAR e OZELLA, 2013), através das quais se torna possível articular os significados contidos nas palavras com o intuito da aproximação das zonas de sentido.

De início cabe ressaltar que a ideia central é a apropriação daquilo que está situado nos níveis mais profundos do indivíduo, portanto, o método empírico do qual se utiliza frequentemente em pesquisas qualitativas, torna-se insuficiente, sendo necessário agregar ao empirismo a penetração por regiões menos aparentes e superficiais da pessoa. Dessa forma, se esclarece que:

[...] nossa reflexão metodológica sobre a apreensão dos sentidos estará pautada numa visão que tem no empírico seu ponto de partida, mas a clareza de que é necessário irmos além das aparências, não nos contentarmos com a descrição dos fatos, mas buscarmos a explicação do processo de constituição do objeto estudado, ou seja, estudá-lo no seu processo histórico (AGUIAR e OZELLA, 2006, p.224).

É essencial que, na fundamentação por meio das categorias, seja levado em consideração os aspectos de complementaridade, similaridade e contraposição, que estão presentes nas falas do sujeito, pois tais aspectos auxiliam no aprofundamento da análise.

Em posse do conteúdo de uma entrevista, que embora não seja objetivo deste estudo caiba enfatizar 
que deva respeitar alguns cuidados em sua elaboração e execução, o roteiro de aplicação dos núcleos de significação consiste na transcrição do conteúdo, seguido de uma leitura flutuante. Depois da leitura deve ser realizado um levantamento dos temas e conteúdos (palavras/expressões) para elaboração dos pré-indicadores, aqueles que representam a realidade sócio-histórica do sujeito. Os pré-indicadores serão organizados num quadro no sentido vertical, dessa maneira, o passo seguinte é a aglutinação deles para a formação dos indicadores, por meio da semelhança, da complementaridade e da contraposição. Os indicadores serão posicionados no mesmo quadro à direita, formando grupos que representam uma consolidação de significados que se dirige para as zonas de sentido. Em seguida, é elaborado o segundo quadro no qual a coluna da direita (indicadores) passa a ser a coluna da esquerda, que será o ponto de partida para a organização dos indicadores em núcleos de significação, seguindo o mesmo método anterior, todavia, os núcleos de significação podem ser gerados a partir de indicadores que não se encontram próximos uns dos outros, e que podem aparecer repetidamente de acordo com a organização (AGUIAR e OZELLA, 2013).

Com os quadros estruturados, os dados estarão organizados de forma a permitir o início da análise, que deverá ser feita intranúcleo, explorando ao máximo os dados contidos em cada núcleo. Em seguida será realizada a análise internúcleos na qual se refletirá sobre a apreensão dos sentidos de cada núcleo de forma a obter uma síntese, que tem como finalidade a máxima aproximação das zonas de sentido (AGUIAR e OZELLA, 2013).

Dessa forma, denominaremos o sujeito com o qual foi realizada a entrevista como S1, e seguiremos o roteiro apresentado para a análise por meio dos núcleos de significação. A seguir apresenta-se os quadros 1 e 2, e a posteriori as respectivas análises.

Cabe ressaltar que, em busca aberta nos sites de pesquisa de periódicos e artigos científicos do Google Acadêmico, Scielo e CAPES foram encontrados cerca de 130 trabalhos que se utilizaram do método dos Núcleos de Significação para análise dos significados e aproximação das zonas de sentido. Este volume de estudos relacionados ao tema está contido num período pouco maior que 10 anos, sendo que um artigo datado de 2006 cuja referência está presente neste estudo é dos mais distantes identificados em nossa busca.

Em tempo, estudiosos do núcleo de Psicologia Sócio-Histórica da PUC-SP aparecem como os principais originadores de trabalhos na área na medida em que apresentam o método em sua forma de uso orientando sobre como aplica-lo, mais do que propriamente fazendo uso do método pura e simplesmente. 


\section{Quadro 1 - Organização dos Indicadores e Pré-indicadores}

\begin{tabular}{|c|c|}
\hline Pré-indicadores & Indicadores \\
\hline 1) Seguir na área de pesquisa. & 1) Declaração da escolha do campo de \\
\hline 2) Pretendo fazer engenharia. & $\begin{array}{l}\text { conhecimento desejado para formação superior } \\
\text { na área de exatas, com atuação em pesquisa. }\end{array}$ \\
\hline
\end{tabular}

4) […] não tem [...] questão de faculdade.

5) [...] pra campo de estudos seria no máximo a UNESP que também tem.

2) Dificuldade em identificar universidades que tenham cursos compativeis com sua escolha.

6) [...] talvez eu faça algum estudo sobre isso, só que tem que depois em outro lugar continuar.

7) [...] formação escolar, ela é a base de tudo.

8) [...] se tiver uma base escolar fraca.

9) [...] foi conciliado com meus pais a estudar.

10) [...] ou eu estudo ou eu não vou conseguir alcançar isso.

3) Projeção da escola e da formação como condição preponderante para alcançar a carreira

11) [...] faço, desde cursinho pré-vestibular, que eu faço aos sábados, desde Técnico, faço Técnico Mecânico que eu faço na ETEC [...] Curso de Informática eu fiz [...]

12) Meu pai terminou o ensino médio e minha mãe só o fundamental.

13) Meu pai já foi caldeireiro, mecânico [...] não tem um ofício específico. Minha mãe é dona de casa. Meu pai tá desempregado [...] a vida inteira trabalhou em indústria.

4) [...] forte referência na história de vida profissional dos pais que não consolidaram carreiras, supostamente por falta de formação escolar.

14) [...] sucesso profissional ou algo do tipo, financeiramente, não.

15) [...] o meu pai perdeu muita oportunidade.

16) [...] meu pai, ele já trabalhou até de projetista.

17) [...] ele é bom nessa parte [...] ele é ótimo, você dá um trabalho pra ele e ele faz em pouco tempo.

18) [...] meu pai acho que não, tanto que ele tá fazendo técnico mecânico junto comigo (sobre ser realizado).

19) [...] porque quando ele viu que eu queria uma área próxima à dele, ser técnico, essas coisas, ele pensou que também poderia voltar a estudar [...] eu sou filho único.

20) [...] ela diz que pra você ter a ISO você tem que ter só técnicos pra cima na sua empresa.

21) [...] surgiu várias oportunidades de emprego, assim, financeiramente bom, Embraer e outros lugares também, só que quando ele chegou lá o cara perguntava: você tem técnico? Não, eu não tenho técnico.

22) [...] porque antigamente não tinha como fazer técnico, então as pessoas mais velhas que tem experiência, tem capacidade, estão colocadas em empregos baixos.

5) [...] crítica à filosofia do diploma e ampliação da situação vivenciada pelo pai para a sociedade de uma forma geral; ponto de estímulo para o empenho nos estudos como forma de 'vingar' a história profissional do pai, mostrando que ele, diferentemente, pode construir uma carreira próspera e sem limites.

23) Ele é bem sucedido sim (sobre o pai) só que por esse fato ele não é mais, que ele poderia ser, poderia ser mais.

24) Atrelar os dois é sempre interessante.

25) [...] só que no começo é difícil encontrar o que te dê prazer pra trabalhar.

26) [...] a questão econômica pra se manter.

27) [...] ter uma vida boa.

7) Busca por uma carreira que tenha sentido.

28) [...] prefiro muito mais ter prazer do que ganhar rios de dinheiro.

29) Eu me perguntaria: eu estou feliz com o que eu estou fazendo?

30) [...] nós não somos compostos só de um ponto, entendeu?

6) Sentimento de relativa revolta com o sistema (mercado de trabalho e suas regras) que, segundo sua visão, restringiu o crescimento profissional do pai. 
31) É como se eu te desse uma vara, mas não te ensinasse a pescar!

32) [... ] você deve estudar pra conseguir algo bom na sua vida.

33) [...] nesse ano a gente só foi para um feira de profissões.

34) [...] ela influenciou um pouco.

35) [...] sempre conversei bastante com professores.

36) [...] vou arranjar um emprego por aqui.

37) [...] tem como eu trabalhar lá.

38) [...] acho que algumas filosofias, eu não concordo muito.

39) [...] falta oportunidade para as pessoas.

40) [...] se eu não conseguir emprego ali, aonde eu vou conseguir emprego?
8) Os recursos de orientação profissional ofertados pela escola são insuficientes, então é necessário iniciativa e autonomia na busca por respostas.

9) Faltam oportunidades e alternativas, logo, se 0 individuo não estiver disposto a sair da cidade, independentemente dos seu motivos, a grande indústria instalada no município torna-se praticamente a determinação de uma escolha única.

41) [...] é a oportunidade única que elas tem.

42) [...] pra empreender sim.

43) Acho que eu empreenderia.

44) [...] aqui é muito focalizado em indústria.

45) [....] é uma ótima cidade pra turismo.

46) [...] tem tudo para virar uma cidade universitária.

47) [...] é uma cidade histórica.

48) [...] eu adoro a parte de exatas.

49) [...] eu me dou bem também é na parte de filosofia, na parte de história.

10) Apelo pela descentralização da atividade econômica do município, deixando como sugestão o estímulo ao empreendedorismo.

50) [...] lidar com humanas, com pessoas.

11) O processo de escolha que parecia estar totalmente resolvido ainda dá espaço para impasses relevantes.

51) Seria mais com meu pai e com alguns amigos.

52) Nunca fiz um teste vocacional.

53) Espero me realizar.

54) [...] espero alcançar meus objetivos.

12) Realização por meio de metas profissionais

55) [...] sentir feliz alcançando esse objetivo.

56) [...] construir uma família.

57) [...] dar uma boa educação para os meus filhos.

58) [...] seria eu chegando 8:00 horas em meu próprio laboratório. $\quad$ 13) Projeção do "eu" adulto.

59) [...] iniciando minha pesquisa.

60) [...] talvez com meus alunos.

61) [...] a ciência está evoluindo muito.

62) [...] simulações com vida ou com DNA.

63) [...] precisa de computadores para poder filtrar esses dados.

64) [...] computação quântica.

65) [...] se eu conseguir um material que faça o computador ter um alto desempenho.

14) Traços de idealização ambivalentes, com perfil ao mesmo tempo altruísta e individualista.

66) [...] dar aos estudiosos uma ferramenta.

67) [...] uma ferramenta que auxiliasse na cura do câncer, da aids, da malária, da dengue.

Fonte: SILVA, J.E. (2017) 


\section{Quadro 2 - Organização dos Indicadores e Núcleos de Significação}

\begin{tabular}{|c|c|}
\hline Indicadores & Núcleos de significação \\
\hline $\begin{array}{l}\text { 1) Declaração da escolha do campo de } \\
\text { conhecimento desejado para formação superior } \\
\text { na área de exatas, com atuação em pesquisa. }\end{array}$ & $\begin{array}{l}\text { 1) Identificação de gostos e aptidões profissionais vinculados a uma } \\
\text { análise das restrições. }\end{array}$ \\
\hline
\end{tabular}

1) Declaração da escolha do campo de conhecimento desejado para formação superior na área de exatas, com atuação em pesquisa.

2) Dificuldade em identificar universidades que tenham cursos compativeis com sua escolha.

9) Faltam oportunidades e alternativas, logo, se o individuo não estiver disposto a sair da cidade, independentemente dos seu motivos, a grande indústria instalada no município torna-se praticamente a determinação de uma escolha única.

11) O processo de escolha que parecia estar totalmente resolvido ainda dá espaço para impasses relevantes.

3) Projeção da escola e da formação como condição preponderante para alcançar a carreira desejada.

4) [...] forte referência na história de vida profissional dos pais que não consolidaram carreiras, supostamente por falta de formação escolar.

5) [...] crítica à filosofia do diploma e ampliação da situação vivenciada pelo pai para a sociedade de uma forma geral; ponto de estímulo para o empenho nos estudos como forma de vingar a história profissional do pai, mostrando que ele, diferentemente, pode construir uma carreira próspera e sem limites.

2) A contextualização do ambiente em que está inserido e a admissão da possibilidade de alteração da escolha profissional.

6) Sentimento de relativa revolta com o sistema (mercado de trabalho e suas regras) que restringiu o crescimento profissional do pai.

8) Os recursos de orientação profissional ofertados pela escola são insuficientes, então é necessário iniciativa e autonomia na busca por respostas

9) Faltam oportunidades e alternativas, logo, se o indivíduo não estiver disposto a sair da cidade, independentemente dos seu motivos, a grande indústria instalada no município torna-se praticamente a determinação de uma escolha única.

10) Apelo pela descentralização da atividade econômica do município, deixando como sugestão o estímulo ao empreendedorismo.

3) Vinculação do papel da escola com a trajetória profissional.

7) Busca por uma carreira que tenha sentido.

12) Realização por meio de metas profissionais.

13) Projeção do "eu" adulto.

5) Construção do processo de autoconhecimento.

14) Traços de idealização ambivalente, com perfil ao mesmo tempo altruísta e individualista

Fonte: SILVA, J.E. (2017) 


\section{NÚCLEO 1: IDENTIFICAÇÃO DE GOSTOS E APTIDÕES PROFISSIONAIS VINCULADOS A UMA ANÁLISE DAS RESTRIÇÕES}

$\mathrm{O}$ sujeito $\mathrm{S} 1$ inicia a entrevista relatando sua clareza de que a área de exatas representa o campo de conhecimento com o qual ele tem maior identificação. Não obstante, S1 articulou um nível de planejamento relevante para a futura carreira profissional, afinal, sua fala revela que a escolha por engenharia de materiais ou química se constitui apenas como a fase inicial da trajetória profissional, na qual S1 afirma ter planos de se aprofundar no ramo da pesquisa; S1 diz ainda ter em mente o objetivo de trabalhar num projeto que diz respeito à descoberta de novos materiais que tenham a capacidade de substituir outros, já conhecidos, no sentido de suprir demandas relacionadas à capacidade de processamento dos computadores com o objetivo fim de auxiliar a medicina na descoberta de doenças que atingem pessoas ao redor de todo o mundo atualmente, ele assim se expressa:

[...] uma questão hoje em dia é que a ciência está evoluindo muito, só que com essa complexidade da ciência, a mente humana não está conseguindo acompanhar ela, então, vira e mexe o tratamento de dados muito grandes precisa de computadores para poder filtrar esses dados ou chegar numa simulação desses dados, então pensando numa questão de medicina, de biologia, simulações com vida ou com DNA é difícil você ter, então, eu vejo que é uma área que está crescendo muito que é a computação quântica [...] se eu conseguir um material que faça o computador ter um alto desempenho, mesmo em temperaturas ambientes normais, porque a computação quântica, ela só funciona em temperaturas muito baixas, próximo de zero [...] dar aos estudiosos uma ferramenta [...] uma ferramenta que auxiliasse na cura do câncer, da aids, da malária, da dengue $[\ldots]$ (S1).

Apreende-se da fala do sujeito S1 a escolha profissional decorrente do interesse despertado a partir de referências construídas desde a infância, na medida em que afirma:

[...] eu sempre, desde criança, a gente assistia, tudo sobre pesquisa, Discovery Channel, e depois com a Internet eu acessava os sites, os blogs, tudo sobre ciência (S1).
A disponibilidade de informação em quantidade abundante na TV e na Internet colocam o jovem no papel de responsável pelo processamento desta massa de dados, portanto, existe a percepção por parte do indivíduo de que a escolha profissional já pode ser feita, inclusive sem a necessidade da ajuda de outrem. Ao fazê-lo sem orientação profissional de qualquer espécie, depositando nas informações obtidas todo processo de escolha, o jovem segue ampliando seu imaginário sobre o futuro profissional, aparentemente, sem o ônus da dúvida.

Observa-se que a definição do curso pretendido não é a origem do processo de escolha, pelo contrário, é a consequência. Recorrendo à categoria mediação é possível extrair o sentido da escolha pela faculdade de engenharia de materiais ou química que em última análise pelo sujeito $\mathrm{S} 1$ trata-se do curso que possibilitará o atingimento do seu objetivo final já idealizado e que nasceu das suas referências do passado, pois "Ao utilizarmos a categoria mediação possibilitamos a utilização, a intervenção de um elemento/processo em uma relação que antes era vista como direta, permitindo-nos pensar em objetos/ processos ausentes até então" (AGUIAR e OZELLA, 2013, p.302).

Assim como a categoria mediação auxilia nesta análise, a categoria historicidade também tem relevância, pois "Tal categoria nos permite olhar para realidade e pensa-la em movimento e, mais do que isso, apreender seu movimento" (AGUIAR e OZELLA, 2013, p.302). Ao refletir sobre os elementos que compõem as experiências do sujeito S1, numa infância dada ao contato com programas e documentários sobre ciências exatas e biológicas, e numa adolescência pautada pelo avanço dos meios eletrônicos de comunicação, constata-se que a categoria historicidade está dada.

Analisando ainda o núcleo 1 , o sujeito $\mathrm{S} 1$ admite a existência de dificuldades com relação ao curso que o levará até o objetivo final, pois as alternativas em termos de universidades são escassas.

Porque aqui no Brasil não tem muito, tipo dessa pesquisa científica tão avançada assim, tem alguns que fazem somente com o mestrado pra depois dar aula, [...] questão de faculdade tem na USP, se não me engano Engenharia dos Materiais [...] pra campo de estudos seria no máximo a UNESP que também tem, só que ela é voltada para Engenharia 
Aeronáutica, materiais para aeronáutica, talvez eu faça algum estudo sobre isso, só que tem que depois em outro lugar continuar essa pesquisa [...] (S1).

Dessa forma, acentua-se a percepção de que a escolha do curso superior ocupa papel instrumental neste processo, sendo este um significado revelado pelo indivíduo em sua fala, que, entretanto, preserva em si o sentido da escolha de fato que reside na atuação como pesquisador em busca de inovação, assim:

As palavras entram na estrutura das coisas e adquirem um determinado significado funcional, do mesmo modo que a vara, para o chimpanzé, torna-se parte da estrutura de obtenção do fruto, adquirindo o significado funcional de instrumento (VIGOTSKI, 2008, p.154)

Em síntese, com a aplicação das categorias mediação e historicidade, o presente núcleo de significação por meio da análise intranúcleo apreende que o 'desejo do grande feito científico' é o que mais se aproxima das zonas de sentido compreendidas nas falas do indivíduo. Todavia, se pretende maior aproximação destas zonas de sentido na análise internúcleos, que nos parece oferecer elementos mais relevantes para a reflexão.

\section{NÚCLEO 2: A CONTEXTUALIZAÇÃO DO AMBIENTE EM QUE ESTÁ INSERIDO E A ADMISSÃO DA POSSIBILIDADE DE ALTERAÇÃO DA ESCOLHA PROFISSIONAL}

A análise intranúcleo referente ao núcleo 2 apresenta um viés de semelhanças com o núcleo 1 na medida em que comporta as questões da escassez de universidades que ofertam cursos compatíveis com a escolha feita e também com o processo de escolha em si. Mas, de maneira complementar o núcleo 2 também considera aspectos que abrem espaço para a discussão de alguns fatores presentes no município que podem exercer influência na escolha, bem como a própria revelação por parte do sujeito de que alguns segmentos da área de ciências humanas lhe são atraentes.

Neste momento da entrevista, apesar de toda a firmeza mostrada com relação à escolha pela área de ciências exatas no início da sua fala, $\mathrm{S} 1$ se permite pensar na hipótese de uma carreira noutro campo de conhecimento, ao dizer que:
[...] eu adoro a parte de exatas, mas o que eu me dou bem também é na parte de filosofia, na parte de história [...] lidar com humanas, com pessoas, eu também seria realizado [...]. Nunca fiz um teste vocacional (S1).

Ao afirmar que nunca fez um teste vocacional, sua expressão revela quanto a orientação profissional ainda está distante das escolas e da realidade do jovem do ensino médio, quer pelo termo ultrapassado utilizado pelo indivíduo, quer pela sua percepção de que um processo de escolha da profissão possa ser reduzido a um mero teste. $\mathrm{O}$ caráter datado da expressão pode ser constatado no relato que esclarece o que estava ocorrendo no Brasil a partir da segunda metade do século XX ao entendermos que:

Os instrumentos dos Orientadores Educacionais para a tarefa de Orientação Profissional eram as baterias de sondagem de aptidões e habilidades, testes de inteligência, inventários de interesses e informações ocupacionais; ou seja, o chamado modelo clássico de Orientação, os "Testes Vocacionais" (UVALDO e SILVA, 2010, p.31).

De qualquer forma, para além desta preocupação, é prioritário observar que se configura aqui a contraposição na fala do sujeito. Uma declaração anterior que dava conta de uma escolha pelas ciências exatas de maneira aparentemente indubitável, num outro momento admite a receptividade e familiaridade com as ciências humanas, o que de certa forma, no tocante à atuação, constitui um paradoxo.

Todavia, a admissibilidade de diferentes campos de conhecimento demonstra o aspecto do processo em aberto pelo qual todo indivíduo passa, não só na adolescência, mas no decorrer de toda a vida, apesar de uma realidade social que exerce pressão para que haja "[...] uma adolescência submetida à ilusão de que a escolha profissional, uma vez feita, será única e duradoura para toda a vida" (MANSANO, 2003, p.47).

Entretanto, nos parece que S1 não percebe que a possibilidade de ponderar entre as áreas de exatas e de humanas seja um fator que enriquecerá seu processo de escolha. $\mathrm{O}$ sujeito considera sua escolha pela área de exatas definitiva e expõem a possibilidade da mudança para área de humanas como uma condição remota e acima de tudo contingencial. Quando o sujeito S1 não se permite uma abertura para a discussão sobre 
a escolha da profissão, tendo-a como resolvida, ele próprio inibe o caráter sócio-histórico contido em sua trajetória, o que pode lança-lo num futuro profissional que exija dele próprio mais redefinições estruturais do que seria necessário se sua historicidade fosse considerada no presente momento.

Sobre os fatores de influência presentes, ao descrever sua percepção sobre as oportunidades existentes no município onde mora, o sujeito S1 fornece subsídios que ajudam a entender tais questões, ao demonstrar algumas preocupações, tais como:

[...] falta oportunidade para as pessoas.

[...] se eu não conseguir emprego ali, aonde eu vou conseguir emprego?

[...] o problema é que se acontece algo errado nessa empresa, todo mundo sofre.

[...] é a oportunidade única que elas tem.

Logo, analisando a fala pela perspectiva da categoria historicidade, observa-se que apesar do idealismo contido na declaração da escolha pela área de engenharia com ênfase na pesquisa, bem como o objetivo ousado contido no projeto de vida profissional, a escolha do sujeito $\mathrm{S} 1$ é também carregada fortemente com o aspecto da contraposição presente na necessidade de se afastar tanto quanto for possível da realidade vivenciada pelos adultos que se submeteram às condições de contorno existentes no município.

Nesse caso, qualquer escolha que não direcione a vida profissional de S1 para situações de dependência extrema da grande empresa instalada no município, será benvinda. Assim, a categoria mediação novamente auxiliará no entendimento de que optar por um curso que não está disponível na cidade onde mora, por uma área de atuação que provavelmente só será possível em localidades muito distantes, e ainda, idealizar uma meta ousada que traga consigo alta complexidade, pode denotar não só aptidão e gosto, mas uma fuga declarada em relação ao contexto conhecido, o que parece se aproximar mais das zonas de sentido para S1 neste caso.

\section{NÚCLEO 3: VINCULAÇÃO DO PAPEL DA ESCOLA COM A TRAJETÓRIA PROFISSIONAL}

Depois da família, a escola é a instituição que passa a fazer parte da vida do indivíduo com maior brevidade. Atualmente há uma crescente procura por modelos que sirvam simultaneamente aos propósitos da alfabetização, da socialização e da guarda (creche). Por conta disso as crianças iniciam sua história de vida escolar mais precocemente que outrora, portanto é razoável inferir, numa perspectiva não aprofundada e sem levar em conta quaisquer outros elementos, que a escola no século XXI ganha mais relevância no processo social e histórico dos indivíduos por uma questão de ampliação presencial.

Outrossim, não se questiona que a escola, independentemente de uma atuação de caráter tradicional ou contemporâneo, ocupa um espaço importante na formação ideológica do indivíduo, logo, quanto mais se aproximam os anos finais do ensino médio, maiores são as interações sobre o debate acerca do futuro profissional dentro do ambiente escolar. $\mathrm{O}$ sujeito $\mathrm{S} 1$ deixa isso explícito em sua fala ao afirmar que:

[...] a formação escolar, ela é a base de tudo, então, se tiver uma base escolar fraca, em sua vida dificilmente você vai alcançar o que você almeja, na questão que eu quero, então, desde cedo, foi conciliado com meus pais a estudar e quando eu vi que eu queria isso, eu falei: ou eu estudo ou eu não vou conseguir alcançar isso (S1).

No entanto, S1 expõem outros significados que parecem transpor a mera relação entre o papel da escola e a escolha da profissão. Ao dizer que:

[...] tudo aqui [...] faço, desde cursinho prévestibular, que eu faço aos sábados, desde Técnico, faço Técnico Mecânico que eu faço na ETEC [...] Curso de Informática eu fiz [...] (S1).

O que pode ser entendido como esforço extra com objetivo de ampliar a capacitação, diversificar conhecimentos, aumentar as chances no vestibular, etc., também pode ser lido como a busca não necessariamente organizada, com algum desperdício de energia e com o foco somente na quantidade de eventos, deixando em aberto a possibilidade de pensarmos numa suposta falta de objetivo. 
Ora, se a escola é um significado apreendido na fala do sujeito de maneira direta e para além disso depreende-se sentido no ato de tentar estar presente em tantos espaços de formação quanto forem possíveis, soma-se a tudo isso novos significados contidos nas questões a partir das quais $\mathrm{S} 1$ estabelece relação entre a formação escolar dos pais com a não realização profissional deles.

Meu pai já foi caldeireiro, mecânico [...] não tem um ofício específico. Minha mãe é dona de casa. Meu pai tá desempregado [...] a vida inteira trabalhou em indústria (S1).

Mais do que um simples relato das ocupações dos pais, o sujeito parece querer expressar certo pesar numa relação de causa e efeito na qual a falta de ofício levou ao desemprego atual, a mesma falta de ofício que foi gerada pela falta da formação escolar. Aproxima-se, dessa forma, às zonas de sentido por trás dos significados da fala de S1. Torna-se ainda mais latente o incômodo que a história profissional do pai representa para S1 mediante o seguinte relato:

Eu já observei, tanto que até o que, eu acho que tem a ISO, ela... ISO9000 ou coisa do tipo, ela diz que pra você ter a ISO você tem que ter só técnicos pra cima na sua empresa, por causa disso, o meu pai perdeu muita oportunidade, porque o cara conhecia o trabalho dele, falava assim: gostei do seu trabalho! Meu pai, ele já trabalhou até de projetista, fez curso de Autocad, Catia, ele é bom nessa parte [...] ele é ótimo, você dá um trabalho pra ele e ele faz em pouco tempo, e tipo, surgiu várias oportunidades de emprego, assim, financeiramente bom, Embraer e outros lugares também, só que quando ele chegou lá o cara perguntava: você tem técnico? Não, eu não tenho técnico [...] eu acho, que essa questão de filosofia do diploma, eu acho às vezes certo, pra você criar um técnico, um profissional, mas sei lá, acho que não tão interessante, porque antigamente não tinha como fazer técnico, então as pessoas mais velhas que tem experiência, tem capacidade, estão colocadas em empregos baixos, inferiores, ou seja, vejo muita gente fazendo curso técnico comigo que já é velha, tem grande talento e que tem empregos medianos, porque se fosse realmente o talento deles eles seriam muito melhor aproveitados [...] Ele é bem sucedido sim, só que por esse fato ele não é mais, que ele poderia ser, poderia ser mais $(\mathbf{S 1})$.

Diante de uma forte carga afetiva vinculada à figura do pai, na medida em que S1 foi apropriando-se da sua história profissional e construindo um misto de admiração e respeito pela capacidade por ele designada ao pai, em face à profunda decepção de não ter a oportunidade de presenciar o êxito profissional dele através de um emprego prestigiado, de um cargo bem remunerado e de um status sócio/profissional a altura do merecimento por S1 dirigido ao pai, de forma inconsciente a incansável busca por formação escolar talvez possa ser explicada pela repulsa à história de vida profissional do pai, cuja trajetória S1 não pretende repetir.

À luz da categoria necessidade/motivos se pode inferir que a escola torna-se para o sujeito S1 o motivo que trará satisfação para sua necessidade de ruptura com a trajetória profissional dos pais, pois " [...] a necessidade completa sua função quando 'descobre' na realidade social o objeto que poderá satisfazê-la" (AGUIAR e OZELLA, 2013, p.306).

Dessa forma, o núcleo 3 apresenta relevante aproximação das zonas de sentido na medida em que a fala do sujeito forneceu significados sobre a escola e sobre a questão profissional dos pais em contextos isolados entre si, contudo a complementaridade e a contraposição contida neles levou à inferência do sentido presente na superação da frustração profissional dos pais vivenciada por $\mathrm{S} 1$ por meio da formação escolar.

\section{NÚCLEO 4: RUPTURA COM O MODELO VIGENTE E BUSCA POR NOVAS POSSIBILIDADES}

De forma oposta ao que foi observado no núcleo 3 em que o sujeito valoriza o papel da escola e demonstra tal representação através da interação com vários cursos extracurriculares, aqui é apresentada outra face da mesma escola, na qual o debate específico sobre o futuro profissional e seus desdobramentos no presente parecem pouco explorados. Ao ser perguntado sobre como enxerga o papel da escola no seu processo de conhecimento a respeito do mundo profissional, S1 respondeu:

É como se eu te desse uma vara, mas não te ensinasse a pescar! (S1)

Essa fala do sujeito foi proferida num formato que por si só requer uma análise contextual. O significado neste caso não é direto, pois a linguagem 
é de caráter simbólico, portanto, a reflexão recai sobre o próprio sentido contido na frase. A pergunta feita ao sujeito apresenta dois atores, 'o papel da escola' e o 'mundo profissional', logo, por meio da categoria mediação infere-se que a frase indica que a escola oferece várias disciplinas - 'te dá uma vara' - mas não ensina como usar - 'não te ensina a pescar'. O sentido aparente desta afirmação aponta para uma escola que se preocupa com o cumprimento da grade curricular pré-determinada, mas não se dá conta da necessidade de conferir unidade a este conjunto de conhecimentos de forma que o indivíduo possa, de fato, aplicar ao máximo o aprendizado construído até aquele momento para uma escolha que tenha menos incertezas, portanto, maior relação com sua historicidade.

No desenvolvimento dos seus estudos sobre a conexão entre a fala e o pensamento, Vigotski apresentou o que chamou de análise das unidades, onde alerta para os riscos da fragmentação que "[...] faz-nos incorrer em sérios erros, na medida em que ignoramos a natureza unitária do processo em estudo" (VIGOTSKI, 2008, P.4), de tal forma, analogamente aproxima-se das zonas de sentido da fala do sujeito S1. Completa-se a ideia conceitual com a afirmação de que "Com o termo unidade queremos nos referir a um produto de análise que, ao contrário dos elementos, conserva todas as propriedades básicas do todo, não podendo ser dividido sem perdê-las" (VIGOTSKI, 2008, p.5).

Nos trechos de fala seguintes $\mathrm{S} 1$ dá significados para diferentes situações vividas na escola que se assemelham e se complementam:

[...] nesse ano a gente só foi para uma feira de profissões.

\section{[...] ela influenciou um pouco (a escola).}

[...] sempre conversei bastante com professores.

De certa forma, o sujeito indica que o processo de escolha profissional durante o ensino médio foi assumido pelo jovem, pois não houve um projeto estruturado para orientação profissional dentro da escola. Assim, ficou a cargo de cada aluno elaborar, ao seu modo, suas formas de escolha.

Não se opõem ao fato de que a escolha seja construída pelo indivíduo, pelo contrário, dentro da perspectiva sócio-histórica entende-se que somente o sujeito, com sua unicidade histórica, tem esta possibilidade, todavia, faz-se necessário chamar a atenção para importância de apoiar o jovem em sua formação, não somente técnica e disciplinar, mas, sobretudo crítica; tal tarefa nos parece deveras difícil de ser alcançada pelo adolescente solitário, sem nenhum suporte da escola. A esse respeito entendemos que:

[...] caberia ao profissional ajudar o indivíduo a entrar em contato, de maneira efetiva, com os múltiplos aspectos presentes não apenas em uma escolha, mas na trajetória de construção do vínculo com o trabalho, de maneira que esse vínculo possa ser analisado considerando sua historicidade, sua dimensão de inacabamento e sua dimensão criadora (MANSANO, 2003, pp.142-143).

Não obstante, mudando o olhar de dentro da escola para fora dela, o mercado local apresenta escassez na oferta de oportunidades.

[...] algumas pessoas, não digo algumas, mas muitas pessoas visam essa educação industrial para trabalhar nessa empresa e em outras, terceirizadas aqui [...] é a oportunidade única que elas tem [...] (S1).

Essa realidade parece estimular o jovem a atrair-se por duas possibilidades, sendo a primeira delas, buscar cursos de formação superior fora do município, enquanto a outra seria a incorporação do perfil empreendedor. Ao ser perguntado sobre a possibilidade de sair para trabalhar fora da cidade e depois de algum tempo retornar, o sujeito S1 afirmou:

Acho que trabalhar em empresa é até um pouco difícil, mas pra empreender sim. Acho que eu empreenderia. [...] aqui é muito focalizado em indústria [...] é uma ótima cidade pra turismo, uma cidade que tem tudo para virar uma cidade universitária [...] eu vejo que se tivesse uma faculdade forte aqui, pesada, podia [...] porque a cidade é uma cidade histórica [...] tem um potencial pra investir nessa questão de história, tanto que em nossa praça tem um soldado, o documento que assinava o fim desse conflito foi escrito numa escola aqui [...] essa parte de turismo, nós crescemos numa cidade de trem [...] (S1).

Portanto, no processo de análise do núcleo 4 aproxima-se das zonas de sentido na medida em que os significados trazidos destacam a falta de orientação na escola de forma sistêmica e a escassez 
de oportunidades de trabalho no município, que à luz da categoria necessidade/motivos, são convertidos em empreendedorismo; tal perspectiva pode ser observada em qualquer outro lócus não particularmente cercado pelos aspectos aqui estudados, entretanto não se pode desprezar o estímulo que a escassez de oportunidades promove, posta neste caso com a iniciativa dos jovens em resolver aquilo que as gerações anteriores não resolveram.

\section{NÚCLEO 5: CONSTRUÇÃO DO PROCESSO DE AUTOCONHECIMENTO}

Neste núcleo a fala do sujeito apresenta significados complementares, similares e opostos entre si. Observa-se que, apesar das idealizações do indivíduo e de suas identificações com determinadas nuances profissionais, ainda assim pairam muitas dúvidas e perduram dilemas que não são de fácil resolução, donde se pode inferir que a falta de um trabalho amplo e estruturado de orientação profissional represente uma carência para o jovem nesse aspecto. Nota-se que "A orientação profissional não está atendendo às necessidades dos jovens no âmbito escolar, ou porque geralmente não ocorre ou, quando é realizada deixa muito a desejar" (SOARES, 2002, p.121-122).

No entanto, não se deve esperar esta atuação somente da escola, mesmo porque seria insuficiente. Entende-se que a orientação profissional com potencial para contribuir com o indivíduo de forma sustentada seja aquela na qual o sujeito aprenda a viver num ambiente de incertezas e constantes mudanças sem perder sua capacidade de decidir e de mobilizar suas habilidades no sentido de estar em permanente desenvolvimento. Para tanto, uma reflexão se faz necessária:

De quem é a responsabilidade de realizar a orientação profissional? Do psicólogo? Do orientador educacional? Do sociólogo? Do professor? Essa é uma questão primordial ainda sem resposta. A orientação envolve aspectos pertinentes a cada uma dessas áreas, portanto deveria ser um trabalho de equipe interdisciplinar, com profissionais de todas as áreas trabalhando de forma complementar (SOARES, 2002, p.122).

De qualquer forma, é relevante na presente análise, observar partes da fala do sujeito S1 em momentos iniciais da entrevista onde predomina um tom de afirmação que deixaria poucas dúvidas se a conversa terminasse naquele momento. Entretanto, a partir da estimulação presente na entrevista, o indivíduo é levado a refletir sobre questões que resultam numa fala bastante diferente, com outros significados. Ao ser perguntado sobre uma profissão que lhe dê prazer ou dinheiro, S1 afirma que:

Atrelar os dois é sempre interessante [...] só que no começo é difícil encontrar o que te dê prazer pra trabalhar [...] a questão econômica pra se manter, depois de um tempo que você já fez faculdade, já fez tudo, eu prefiro muito mais ter prazer em fazer aquilo, mesmo recebendo não tanto, mas o suficiente para sobreviver, ter uma vida boa, eu prefiro muito mais ter prazer do que ganhar rios de dinheiro. [...] difícil vai ficar realmente, mas dependeria do que? Eu me perguntaria: eu estou feliz com o que eu estou fazendo? [...] se eu respondesse sim, talvez eu continuaria nessa carreira [...] se eu quisesse crescer, mas se eu perguntasse se eu estou feliz e dissesse não! Aí eu tentaria correr atrás desse primeiro objetivo. [...] nós não somos compostos só de um ponto, entendeu? Então pode ser que no começo ou no futuro talvez eu consiga uma vertente diferente, como eu já pensei muitas vezes em outras vertentes, ou que não, é isso que eu quero, correr atrás realmente, começar tudo do zero e tentar alcançar esse objetivo (S1).

$\mathrm{Na}$ fala do sujeito $\mathrm{S} 1$ também é possível observar significados que não dizem respeito propriamente à carreira ou à formação pretendida, mas sim aos eventuais resultados desta atuação profissional, acreditando, portanto, que a escolha feita proporcionará tal acesso. A esse respeito recorre-se à perspectiva psicanalítica na qual, para o adolescente o futuro não é "“[...] abstrato, mas personificado e, ao mesmo tempo, desconhecido. O futuro é também, para ele, uma família e a sua inclusão no sistema produtivo da sociedade em que vive" (BOHOSLAVSKY, 2015, p.25).

Espero me realizar, espero alcançar meus objetivos, e sentir feliz alcançando esse objetivo [...] se eu conseguir a felicidade juntando com meu objetivo, pra ter uma vida boa, pra construir uma família, pra dar uma boa educação para os meus filhos, eu acho que é isso que eu espero [...] essa realização para o trabalho seria eu chegando 8:00 horas em 
meu próprio laboratório e iniciando minha pesquisa $[\ldots](\mathbf{S 1})$.

No sentido de completar a reflexão sobre o presente núcleo em análise, se considera relevantes os significados observados nas metas almejadas pelo sujeito S1 que parecem se contrapor. Identifica-se o altruísmo contido na ideia de participar indiretamente na descoberta da cura de doenças, como afirma:

[...] dar aos estudiosos uma ferramenta, uma ferramenta que auxiliasse na cura do câncer, da aids, da malária, da dengue (S1).

Todavia, cabe buscar compreender quão mais próximo das zonas de sentido está o altruísmo ou o individualismo, pois o sentido de fato pode residir no genuíno desejo de salvar vidas, ajudar o próximo, facilitar o trabalho de outro profissional, bem como, pode representar a projeção social e econômica do próprio indivíduo. E para além de um extremo ou outro, ambos podem constituir proximidade com as zonas de sentido de $\mathrm{S} 1$, com representatividades semelhantes ou distintas.

As contradições podem ser de tamanha importância neste momento para o adolescente, que podem lança-lo num pensamento que se confunde na própria fala. $\mathrm{Na}$ frase a seguir $\mathrm{S} 1$ refere-se à ciência como algo que pode ter vida própria independentemente da atuação do ser humano, afinal, ela - a ciência 'está evoluindo muito', mas 'a mente humana não está conseguindo acompanhar'. Ora, de que forma a ciência evolui senão por meio do desenvolvimento humano?

[...] uma questão hoje em dia é que a ciência está evoluindo muito, só que com essa complexidade da ciência, a mente humana não está conseguindo acompanhar ela (S1).

Por conta de questões culturais, logo, sóciohistóricas, o sentido por trás da fala do sujeito S1 pode neste caso ser elitista, pois o sentido seria de que a ciência não está ao alcance de qualquer um por assim dizer, seria privilégio de poucos. Sendo assim, a mencionada 'mente humana que não está conseguindo acompanhar' seria representada pela grande parcela de pessoas que não está à altura de compreender, muito menos contribuir para o avanço da ciência.

De qualquer forma, nos parece que todo o percurso de análise do núcleo 5 remete à busca pelo autoconhecimento, em meio à uma profusão de percepções, sentimentos, informações e ideais, ao mesmo tempo se somando e se contrapondo. Talvez a ausência de um roteiro de orientação para o autoconhecimento acentue a dificuldade para o jovem, pois questões norteadoras podem ser relevantes, tais como:

[...] 'quem fui', 'como me tornei assim', 'do que eu gostava e do que eu não gostava', 'o que eu sabia fazer e o que eu não sabia', 'como costumava escolher e resolver meus problemas (como me sentia e a quem recorria)', 'quem eram os meus heróis e por que', 'quais eram os mistérios que me intrigavam', 'quem eu queria ser quando crescer', 'o que meus pais esperavam de mim' e até 'quem sou eu e como sou eu hoje' [...] (VALORE, 2010, pp.72-73).

Mediante a grande complexidade em analisar todos estes significados e tentar se aproximar das zonas de sentido, recorre-se à categoria mediação para dar conta minimamente de tal tarefa. Inferese que o sujeito $\mathrm{S} 1$ imerso na afetividade referida ao pai e sob o sentimento de injustiça provocada pelos modelos impostos pela sociedade, com os quais ele não comunga, e ainda, movido por um intenso desejo de reparar esse passado (que ainda é também presente), escolha desafios duros para si e se prive da oportunidade de compreender melhor suas habilidades, aptidões, gostos e interesses. Procura-se na perspectiva da psicanálise novamente, encontrar uma resposta para esta questão, ao supor que o sujeito:

Pode ter escolhido a mesma profissão do pai, sem que isto se deva, especificamente, a uma identificação. Assim como pode ter escolhido uma carreira completamente diferente e, isso sim, ser devido a uma identificação com seu progenitor. Quando falamos de identificação, referimo-nos à sua função defensiva. Faz sentido, se a situamos como uma forma de superar um conflito ou uma contradição (BOHOSLAVSKY, 2015, p.31).

Portanto, considera-se que o núcleo 5 tem sua proximidade com as zonas de sentido mediante as inúmeras contradições vivenciadas pelo sujeito S1 em busca do autoconhecimento derivadas de sua historicidade, que procura leva-lo para longe da trajetória construída pelo pai. 


\section{ANÁLISE INTERNÚCLEO}

Depois de concluídas as análises intranúcleos de cada um dos 5 núcleos de significação, por meio de uma análise internúcleos será elaborada uma síntese que procurará reunir os elementos mais abstratos significados nas falas do sujeito, aproximando-se tanto quanto possível das zonas de sentido neles contidos.

$\mathrm{O}$ interesse pela área de pesquisa percebido no núcleo 1, segundo a análise, parece estar na raiz das questões dos gostos e aptidões, embora haja restrições de ordem prática referentes à disponibilidade de universidades compatíveis com a escolha. Mas a conclusão do núcleo identificou o grande feito científico como o ponto mais próximo das zonas de sentido, por isso, se supõem que somente os gostos, aptidões e restrições não sejam suficientes para explicar este processo de significação.

Concomitantemente, o núcleo 5, no qual foi analisado o processo de construção do autoconhecimento observou-se a identificação do sujeito com a história profissional do pai baseado numa função defensiva, ou seja, uma referência contrária.

Sendo assim, de forma complementar, o núcleo 5 contribui no entendimento do sentido extraído no núcleo 1 na medida em que a complexidade inerente ao processo de autoconhecimento, contextualizado com a ausência de orientação profissional, pautada pela função defensiva em relação à história profissional do pai, provoca no sujeito o senso de urgência na definição do processo de escolha, que por sua vez encontra abrigo nos gostos e aptidões, e mais que isso, as restrições impostas tem seus valores invertidos, pois a exigência da saída da cidade para estudar fora pode, inconscientemente, passar a ser mais um sentido na direção de afastar-se do ponto de origem da questão. Ou seja, um significado na escolha estruturada que esconde um sentido de urgência causado pela função defensiva em relação à história profissional do pai.

No núcleo 2 a análise aponta para uma fuga em relação ao contexto conhecido no qual o sujeito indica que há fatores relevantes no município, quanto à escassez de opções profissionais aliada à presença de uma indústria de grande porte, que o levarão ao caminho da escolha única, caso permaneça ali. Por isso, a saída da cidade toma cada vez mais relevância, porque representa a possibilidade de não estar preso a um contexto profissional impositivo. Além disso, o perfil do pequeno município é influenciado economicamente pelas atividades industriais em função da grande empresa instalada, logo, boa parte dos serviços e escolas profissionalizantes, e também faculdades, moldam-se às especialidades industriais por conta da demanda prioritária gerada pela empresa. Como consequência, a história do pai perpassa a característica industrial da cidade, portanto, tornase mais um fator complementar aos núcleos 1 e 5, que imprimem na escolha da profissão um tom de urgência.

Como potencial fonte causadora dos significados analisados no núcleo 2, a superação da frustração profissional do pai é capturada na análise do núcleo 3 . Observa-se que as representações negativas que estão em cena, tais como falta de oportunidades e histórico de escolha única, podem ser explicadas pelas questões da formação escolar. O sujeito S1 apresenta como perspectiva do insucesso profissional do pai a falta de certificações e não de capacidade e habilidades, logo, a formação escolar toma o centro da questão.

De forma oposta, o núcleo 4 se apresenta como derivação de todos os outros, pois, as atitudes e pensamentos empreendedores parecem agir como uma maneira de atuar sobre a escassez de oportunidades no município com postura ativa.

Portanto, as análises internúcleos demonstram caráter complementar, que convergem os significados de uma escolha profissional no término do ensino médio baseada nos gostos, aptidões, idealizações e projetos de vida, no posicionamento firme do jovem. Todavia, aproximando-se das zonas de sentido observase uma escolha profissional que aderiu à urgência da definição, influenciada pela identificação com a história profissional do pai com função defensiva e afetada pelo contexto peculiar do município pequeno com a presença de uma indústria de grande porte e seus impactos socioeconômicos.

Ao concordarmos que as escolhas no campo profissional ocorrerão durante todo o percurso do indivíduo e que suas possibilidades de desenvolvimento estarão no processo mediante cada demanda, a trajetória acadêmica e profissional do sujeito S1 uma vez concretizada a partir de sua escolha feita no final do ensino médio, tem toda a possibilidade de êxito no tocante à entrada no mercado de trabalho e no reconhecimento financeiro e social advindo de sua 
atuação. O que se pretende deixar como reflexão são as consequências dos fatores debatidos neste estudo que apontam para uma escolha deficiente em alguns critérios considerados relevantes, provocados por agentes causadores presentes na historicidade do indivíduo e que não foram tratados com a importância que representam, dessa forma, a pergunta que permanece sem resposta é: se o nível de pressão sobre o processo de escolha fosse dosado e a urgência eliminada, com a orientação profissional adequada, o sujeito teria feito a mesma escolha profissional?

É provável que esta pergunta nunca seja respondida, afinal, todos os desdobramentos na vida do sujeito S1 ocorrerão em função da escolha presente e não de uma outra possível sobre a qual debatemos, em função disso, este estudo indica que a orientação profissional ampla e devidamente desenvolvida nas formas debatidas ao longo deste trabalho, podem contribuir de forma significativa para o processo de definição do adolescente no decorrer da conclusão do ensino médio, capacitando-o para compreensão de que o processo de escolha é contínuo e exige autoconhecimento, portanto, o tratamento dos aspectos sócio-históricos que cada indivíduo possui de forma única.

Tal condução da escolha profissional nos parece oferecer condições para que as pessoas tenham maior consciência de suas decisões e de suas consequências, logo, que não mergulhem em crises tão profundas como se observa atualmente, com tantos universitários abandonando seus cursos, com tantos profissionais que se declaram infelizes nos seus trabalhos, e com tantos aposentados que não sabem tratar os aspectos emocionais relacionados com o passado e com o presente profissional.

Entendemos que os núcleos de significação representam um efetivo instrumento de análise para apreensão dos sentidos que podem auxiliar na tratativa da complexidade que reside na tarefa de inferir o que se revela por trás das falas de um indivíduo, como um exercício que exige extremo cuidado e atenção por parte do pesquisador. Dessa forma, sem a pretensão de ter atingido o ponto ideal na compreensão da fala do sujeito S1, mas com a percepção de que o método utilizado nos aproxima muito das zonas de sentido, acreditamos na contribuição do presente estudo no que se refere ao campo dos sentidos e significados.

\section{REFERÊNCIAS}

AGUiAR, W.M.J., OZELLA, S. Apreensão dos sentidos: aprimorando a proposta dos núcleos de significação Revista brasileira est. pedag., Brasília, v. 94, n. 236, p. 299322, jan./abr. 2013.

Núcleos de Significação como Instrumento para Apreensão da Construção dos sentidos Psicologia, Ciência e Profissão PUCSP, São Paulo, 26 (2), p. 222-245, 2006.

BARDIN, L. Análise de Conteúdo. 1.ed. Tradução de Luís Antero Reto e Augusto Pinheiro; São Paulo: Edições 70, 2011.

BOHOSLAVSKY, R. Orientação vocacional: a estratégia clínica 13. ed. São Paulo: Martins Fontes, 2015.

MANSANO, S.R.V. Vida e Profissão: Cartografando trajetórias 1.ed. São Paulo: Summus, 2003.

SILVA, J.E. Adolescentes e a escolha profissional: as influências de uma grande empresa em um pequeno município Dissertação (mestrado) - Universidade de Taubaté, Pró-Reitoria de Pesquisa e Pós-Graduação, 2016.

SOARES, D.H.P. A escolha profissional do jovem ao adulto. 3. ed. São Paulo: Summus, 2002.

UVALDO, M.C.C., SILVA, F.F. In: LEVENFUS, R.S., SOARES, D.H.P., \& colaboradores. Orientação Vocacional Ocupacional. 2. ed. - Porto Alegre: Artmed, 2010.

VALORE, L.A. In: LEVENFUS, R.S., SOARES, D.H.P., \& colaboradores. Orientação Vocacional Ocupacional. 2. ed. - Porto Alegre: Artmed, 2010.

VIGOTSKY, L. S. Pensamento e Linguagem. 4.ed. São Paulo: Martins Fontes, 2008.

Recebido em: 01.04.2017

Aceito em: 23.10.2017 